\title{
Other Transportation Workers
}

National Cancer Institute

\section{Source}

National Cancer Institute. Other Transportation Workers. NCI Thesaurus. Code C122557.

Transportation workers not specifically identified elsewhere. 